\title{
Feasibility Study of Installing Rooftop PV System with Net-Metering Scheme in Iraq
}

\author{
Qasim Kadhim Hunehen ${ }^{1 *}$, Ruqayah Ismael Mohsin'², Al-Sharify Mushtaq Talib ${ }^{3}$ \\ ${ }^{1}$ Planning and Studies office, Ministry of Electricity, Baghdad, Iraq \\ ${ }^{2}$ Industrial Research and Development Department, Ministry of Science and Technology, Baghdad, Iraq \\ ${ }^{3}$ Radiophysics, Electronics and Computer Systems Faculty, Taras Shevchenko National University of Kyiv, Kyiv, Ukraine \\ Email: ^drqasimkh1973@gmail.com, alsharify@univ.kiev.ua, mushtaq.talib2005@gmail.com
}

How to cite this paper: Hunehen, Q.K., Mohsin, R.I. and Talib, A.-S.M. (2020) Feasibility Study of Installing Rooftop PV System with Net-Metering Scheme in Iraq. Journal of Power and Energy Engineering, 8, 55-65.

https://doi.org/10.4236/jpee.2020.810005

Received: September 25, 2020

Accepted: October 26, 2020

Published: October 29, 2020

Copyright (c) 2020 by author(s) and Scientific Research Publishing Inc. This work is licensed under the Creative Commons Attribution International License (CC BY 4.0).

http://creativecommons.org/licenses/by/4.0/

\begin{abstract}
Renewable energy, particularly solar energy, offers a clean and alternative energy source to meet the energy demand for sustainable development in the world. Due to its profitability and viability, PV net-metering scheme has been adopted in many countries. The feasibility of implementation PV rooftop system with net metering in residential, commercial, governmental and industrial sectors in Iraq is demonstrated in this study. A financial model has been developed to investigate the feasibility parameters $N P V, I R R$ and annual savings of $24 \mathrm{kWp} \mathrm{PV} \mathrm{system.} \mathrm{The} \mathrm{results} \mathrm{showed} \mathrm{that} \mathrm{increasing} \mathrm{the} \mathrm{capacity}$ of the PV system in residential and commercial buildings will lead to a profitable investment return and the breakeven point that may make the PV net-metering projects feasible is very close to the tariff applied for the commercial sector $(10.29 \$ \mathrm{c} / \mathrm{kWh})$. In the governmental sector, the tariff needs to increase by $35.1 \%$ to reach breakeven. However, for such net-metering scheme to be attractive and feasible on a wide scale, it is crucial to back it with financial support through soft loans and grants.
\end{abstract}

\section{Keywords}

Feasibility Study, Solar PV System, Net-Metering

\section{Introduction}

The availability of energy services is considered as almost important thing for sustainable development in the world. More energy demand leads the developing countries to double their energy demand in response their growth and is highly unlikely that every person in the developing world will achieve the level of consumption of the average person in the developed world by 2035 [1]. Renewable energy, in particular photovoltaic (PV) technology, offers a clean and alter- 
native energy source that can abate energy-related emissions from conventional fossil fuel. PV rooftop-mounted system has demonstrated to be an economical and technically feasible approach to supply sustainable energy for residential, commercial and governmental buildings [2].

During last year, PV systems with net-metering scheme have been adopted in many countries around the world [3]. Net-metering concept specifies that electricity delivered to the grid from a net metering customer is compensated on a one-to-one basis for electricity purchased from the grid [4]. Particularly, net metering can lead to reduction of maximum demand charges and the overall electricity bill for commercial buildings [5].

The profitability and economic aspects of PV systems are evaluated by calculating the Net Present Value (NPV), Simple Payback Period (SPP), Internal Rate of Return $(I R R)$ and the Profitability Index (PI) [2]. Comparing the economic feasibility of a $3 \mathrm{kWp}$ PV system with different electricity loads that cover main consumer demands in Jordan showed that the best payback period is obtained in systems with an energy consumption of more than $1000 \mathrm{kWh}$ [6]. In the same country, Jordan, the income from installing a residential PV system will be highly feasible and competitive if incentive tariff is applying [7]. Installment of 1 MW rooftop PV system in India is feasible both technically and economically with a saving yearly around $17 \%$ of the total investment cost of the system; i.e. the Simple Payback Period is about 7 years [8].

A positive $N P V$ is achievable and payback period was less than PV panels' lifespan of a PV system used to reduce peak electrical demand of Engineering Faculty building in Indonesia [9]. PV systems would be economically viable in more than $40 \%$ of all Brazilian distribution networks [10] if a $20 \%$ reduction of the specific investment costs and a 5\% discount rate were possible. Under net-metering scheme, [11] showed the LCOE of $25 \mathrm{~kW}$ PV rooftop system was found to be $\$ 0.107$ per $\mathrm{kWh}$ and could be considered as an economically and technically attractive power generation at UAE.

Solar rooftop sizes of less than $10 \mathrm{~kW}$ in Thailand with solar irradiation average $18-19 \mathrm{MJ} / \mathrm{m}^{2}$ per day can provide the same $D P P$, IRR, and $P I$ of 6.1 years, $15 \%$, and 2.57 respectively [12] and as a result, regions with higher solar radiation having the potential to produce electrical power from solar energy will be suitable for investment in solar systems. The techno-economic feasibility evaluation for a rooftop PV system of a typical residential building in Saudi Arabia showed that the proposed system of $12.25 \mathrm{~kW}$ can generate $87 \%$ of the electricity needs of an apartment and the levelized cost of energy and net present value revealed competitive figures of $0.0382 \$ / \mathrm{kWh}$ and $\$ 4378$, respectively which indicate that residential PV installations are an effective option for energy management [13].

In Iraq, the electrical distribution general companies receive the generated power from generation plants with voltage levels $(33 \mathrm{kV}$ and $11 \mathrm{kV})$ and distributed through overhead and underground distribution grid to the participants. The residential, governmental and industrial sectors make up 42\%, 26\% and 23\% 
respectively of the electricity energy consumption [14]. This study is an attempt to understand the feasibility of PV net-metering installations for the above distribution sectors in Iraq. The common parameters, Net Present Value and the Pay-Back Period, are used to determine the profitability of install PV systems.

\section{Methodology}

This study consists of two parts, background about the electricity distribution in Iraq is discussed at first with details concerning with status of the utility grid, and then case studies of implementation of PV solar net-metering scheme in the residential, governmental and industrial sectors are conducted to investigate the feasibility of install PV systems in Iraq.

A Case study of install $5 \mathrm{kWp}$ PV system conducted at first to show the annual savings in the electricity bill for residential sector with different annual consumption. Then, Net Present Value (NPV) and Internal Rate of Return (IRR) which are commonly parameters, used to evaluate the economic feasibility of install PV net-metering system for residential, commercial, government and industrial consumers [15]. The decision making on the investment depends on the value of $N P V$. If $N P V>0$, the investment would add value to the investor and that the project may be accepted. If $N P V<0$, it means that the investment would subtract value from the investor and then the project should be rejected [16]. Equation (1) used to calculate $N P V[17]$ :

$$
N P V=\sum_{0}^{n} \frac{C_{n}}{(1+i)^{n}}-C_{0}
$$

where:

$$
\begin{aligned}
& N P V=\text { Net present value (USD); } \\
& C_{0}=\text { Initial capital cost (USD); } \\
& C_{n}=\text { Annual cash flow at time } n \text { (USD); } \\
& i=\text { Discount rate (\%); } \\
& n=\text { Period of analysis (25 years). }
\end{aligned}
$$

$I R R$ refers to the discount rate value at which the net present value of the cash flow of a particular investment is zero and high $I R R$ indicates that the investment opportunity is favorable [13]; $I R R$ is given by [2]:

$$
\sum_{0}^{n} \frac{C_{n}}{(1+I R R)^{n}}-C_{0}=0
$$

The weighted average cost of capital ( $W A C C$ ) is a common topic in the financial assessment. WACC is calculated as follows [18]:

$$
W A C C=\frac{E}{E+D} \times k_{E}+\frac{D}{E+D} \times k_{D} .
$$

where;

$$
\begin{aligned}
& E=\text { Amount of equity; } \\
& k_{E}=\text { Equity rate of return; } \\
& D=\text { Amount of debt; }
\end{aligned}
$$


$k_{D}=$ Debt interest rate.

In this study, the size of the PV system is assumed to be $24 \mathrm{kWp}$ and the electricity tariff is established as in next section for each sector with no development in this tariff along the period of investment. The expected annual energy output produced from the proposed PV system is 27,000 $\mathrm{kWh} /$ year. The interest rate is assumed to be $(8 \%)$ with 8 years' repayment period.

\section{Background and Iraqi Context}

There are three aspects relevant to PV net metering scheme that have to be addressed in more details:

\subsection{Network Losses}

The concept of net-metering schemes as shown above is to provide the consumer with a mechanism to produce part of his electricity demand. The energy produced locally from PV systems can reduce the technical losses in the network since part of the consumption will be generated locally. According to Renewable Energy Context Report "Iraq is ranked among the Arab states that having the highest electricity Transmission and Distribution (T\&D) losses at around 58.2\%" [19]. Figure 1 indicates the amount of the electricity losses in T\&D in the provinces of Iraq.

It can be consider from Figure 1 the huge amount of lost electrical energy in the Iraqi electrical grid between the transmission network and reaching the users through the distribution networks. Therefore, installing solar energy systems on the distribution network is considered one of the effective solutions to avoid these losses.

\subsection{Electricity Tariff}

Electricity is highly subsidized in Iraq and considered to be one of the cheapest in the Arab region. The heavily subsidized tariff in Iraq is considered as a barrier

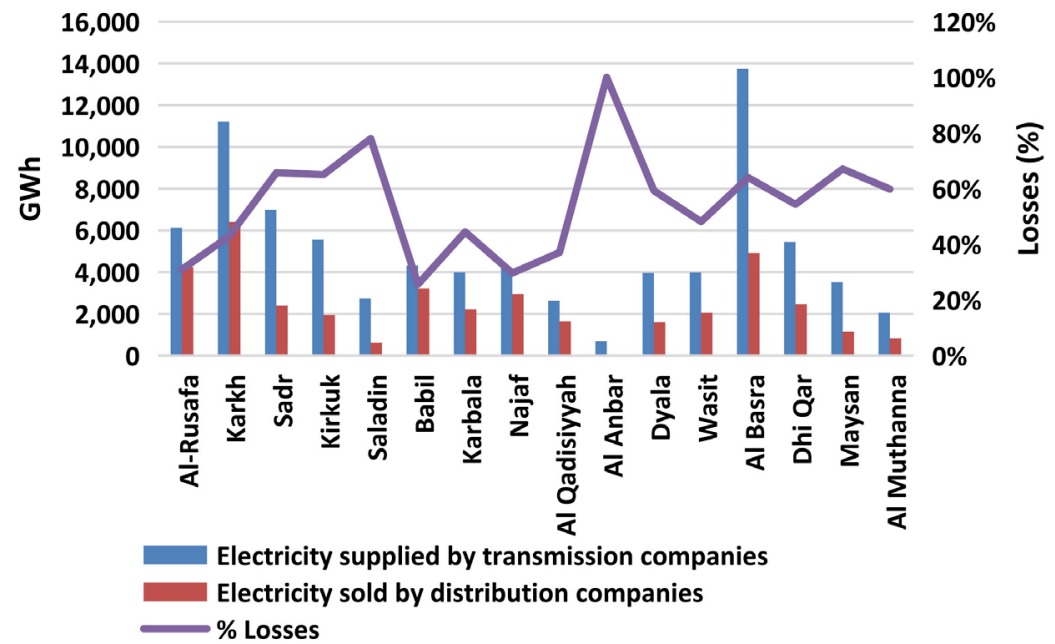

Figure 1. Transmission and distribution losses in Iraq [14]. 
to get tangible results out of PV net-metering scheme since the savings that are supposed to be obtained by installing such scheme are not attractive compared to the initial investments that have to be paid on the start of the project. Figure 2 gives an overview on electricity tariff structure in Iraq [14].

A tariff reform program is highly recommended to give the PV net-metering scheme the self-inertia to promote itself. The figure shows that however the electricity tariff in Iraq is heavily subsidized for most of consumers' categories but still there are some categories that have such a high electricity tariff that maybe attractive for adopting PV net-metering scheme especially the tariff for commercial sector.

\subsection{Reliability and Availability of the Power System}

A crucial prerequisite for net-metering scheme to work properly and to be attractive for local consumer is the existence of reliable and secured power system. The existence of the utility power supply is a prerequisite for Grid-Tie inverter to inject the power generated from the PV panels. Considering the very low reliability indicators of the Iraqi power system the standard PV net-metering scheme is not expected to achieve and sensible records out of it.

\section{Case Studies for Net-Metering Implementation in Iraq}

\subsection{Global Analysis of Net-Metering System}

Figure 3 shows the estimated distribution of monthly consumption as a percentage of the annual consumption. By applying the net-metering scheme considering a system of $5 \mathrm{kWp}$ capacity, the current electricity tariff for the residential sector and considering business as usual such that future updates on the tariff are not considered.

Table 1 shows the annual savings results in USD as well as savings as a percentage of the electricity bill if the solar system was not installed.

Considering the payments for the loan installments after switching to net-

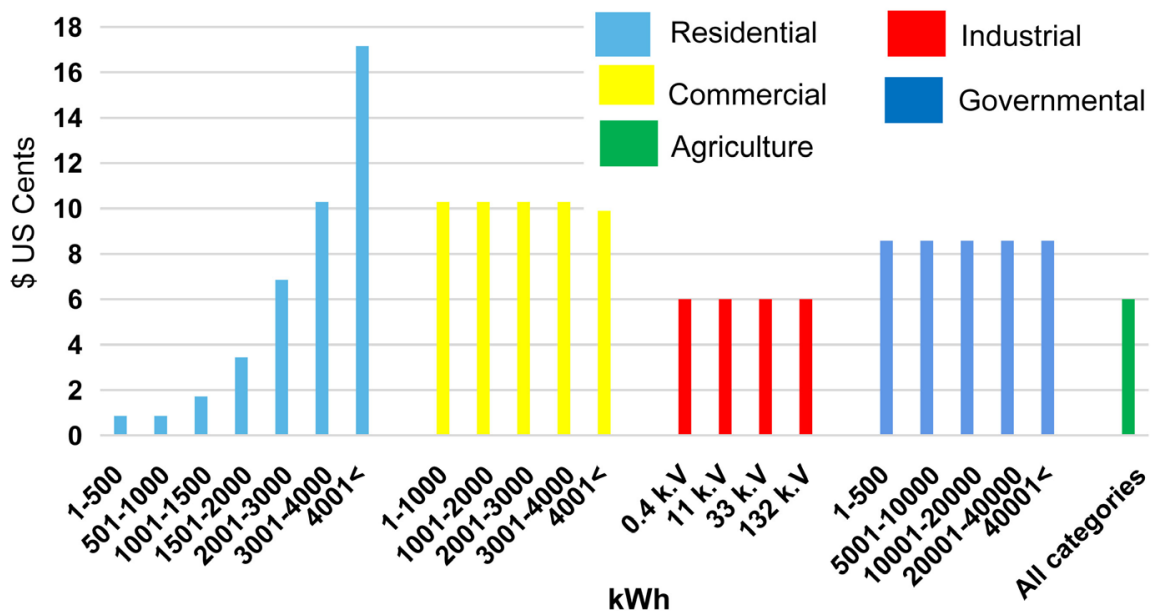

Figure 2. Electricity tariff structure in Iraq [14]. 


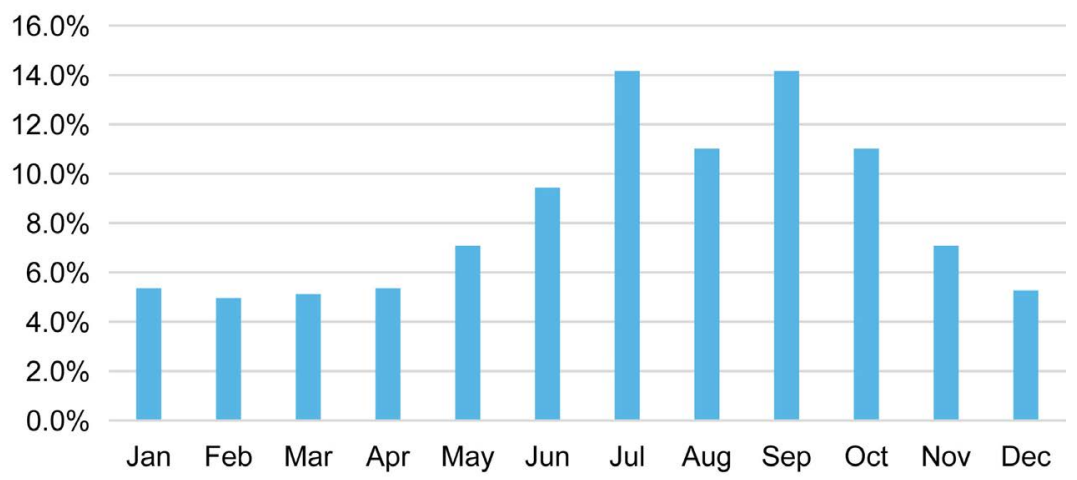

Figure 3. Monthly consumption as a percentage of the annual consumption.

Table 1. Annual savings due to the application of net-metering for different annual consumptions considering the residential sector and utilizing a system of $5 \mathrm{kWp}$ capacity.

\begin{tabular}{lcccc}
\hline \multicolumn{1}{c}{ Annual Consumption (kWh) } & 30,000 & 35,000 & 40,000 & 45,000 \\
\hline $\begin{array}{l}\text { Annual money savings due to net-metering (US\$) } \\
\text { Percentage savings to the annual bill if solar system is not }\end{array}$ & 300.65 & 365.6 & 450 & 580 \\
$\begin{array}{l}\text { installed (\%) } \\
\text { Loan installment coverage ratio }\end{array}$ & $38.4 \%$ & $46.7 \%$ & $57.5 \%$ & $74.1 \%$ \\
\hline
\end{tabular}

metering, the savings will have relatively low covering ratio. Yet, if the tariff increased by $25 \%$ before this switching takes place, the customers consuming 45,000 $\mathrm{kWh}$ per year will achieve a breakeven. However, it is expected the system cost will go down because of economy of scale and the government can offer a restructure if the loan such that break even can be achieved. It is important that these plans are made clear at the start of the governmental program of renewable energy.

\subsection{Sector Analysis of Net-Metering System}

In this section, the net-metering financial model that has been developed under this study will be used to test the feasibility of PV net-metering projects for four categories of consumers; Residential ( $>4000 \mathrm{kWh} /$ month), Commercial, Governmental and Industrial. The inputs parameters in Table 2 for all projects are considered fixed for all four categories except the applied electricity tariff.

\section{Results}

Net-metering applies for both governmental and commercial sectors, where the tariff is flat rate with a value of 8.58 and $10.29 \mathrm{US} \$ \mathrm{c} / \mathrm{kWh}$, the following saving achieves for a system of $5 \mathrm{kWp}$ capacity.

As shown in Table 3, if the tariff increases by $11.2 \%$ for the commercial sector before switching to net metering, the system will payback for itself, without a need to pay additional money. The remaining period after the payment of the loan will enjoy free energy generated from the system. In case of the governmental sector, the tariff needs to increase by $35.1 \%$ to reach breakeven. By applying 
Table 2. Case study inputs parameters.

\begin{tabular}{cc}
\hline Parameter & Value \\
\hline Equivalent Full Operating Hours (hours/year) & 1500 \\
Installed Capacity $(\mathrm{kWp})$ & 24 \\
Specific Investment Cost $(\$ / \mathrm{kWp})$ & 1000 \\
Total Investment Cost $(\$)$ & 24,000 \\
Equity Ratio $(\%)$ & $30 \%$ \\
Debt Ratio $(\%)$ & $70 \%$ \\
Loan's Interest Rate $(\%)$ & $\mathbf{8 \%}$ \\
Repayment Period (years) & $\mathbf{8}$ \\
\hline
\end{tabular}

Table 3. Annual saving due to the implementation of net-metering to both the commercial and residential sectors considering a system of $5 \mathrm{kWp}$.

\begin{tabular}{ccc}
\hline Item & Commercial Sector & Governmental Sector \\
\hline Annual Savings (US\$) & 694.5 & 579.15 \\
Loan Installment Coverage Ratio & $89.2 \%$ & $74 \%$ \\
\hline
\end{tabular}

the equations that mentioned in section 2 in the developed financial model, the results of feasibility study of implementation of PV net-metering scheme with 24 $\mathrm{kWp}$ in residential, commercial, governmental and industrial sectors are summarized in Tables 4-7 respectively, as well as, the annual savings in bills are shown in Figures 4-7.

Net-metering scheme would yield IRRs of $24 \%$ and $13 \%$ for residential and commercial sectors respectively. These are higher than $W A C C$ of $10.10 \%$. It is clear the effect of the fixed electricity tariff value in the governmental and industrial sectors, compared with the residential and commercial sectors. This requires two things, the first is that increasing the capacity of the solar system in houses and commercial buildings will lead to a profitable investment return for these sectors, and the second is the need to increase the electrical tariff for the governmental and industrial sectors in order to encourage adopting such projects.

\section{Conclusion}

A financial model has been developed in this study to investigate the feasibility of implementation PV solar net-metering system in different sectors in Iraq. Based on the above-mentioned analysis, it can be concluded that the breakeven point that may make the $\mathrm{PV}$ net-metering projects feasible is very close to the tariff applied for the commercial sector $(10.29 \$ \mathrm{c} / \mathrm{kWh})$ since the achieved return on equity is $16 \%$ which is very close the target $15 \%$. The results also showed that increasing the capacity of the solar system in houses and commercial buildings has a profitable effect and that it is necessary to increase the electricity tariff for the government and industrial sectors by a percentage. In Iraq, PV could be the optimal alternative to overcome existing power sector challenges and it is recommended 
Table 4. Results for residential sector (>4000 kWh/month).

\begin{tabular}{cc}
\hline Parameter & Value \\
\hline Electricity Tariff $(\$ \mathrm{c} / \mathrm{kWh})$ & 17.15 \\
Weighted Average Cost of Capital (WACC) (\%) & $10.10 \%$ \\
Net Present Value (NPV) (\$) & $\$ 27,290$ \\
Internal Rate of Return (IRR) (\%) & $24 \%$ \\
Achieved Return on Equity (\%) & $\mathbf{4 1 \%}$ \\
\hline
\end{tabular}

Table 5. Results for commercial sector.

\begin{tabular}{cc}
\hline Parameter & Value \\
\hline Electricity Tariff $(\$ \mathrm{c} / \mathrm{kWh})$ & 10.29 \\
Weighted Average Cost of Capital (WACC) (\%) & $10.10 \%$ \\
Net Present Value (NPV) (\$) & $\$ 5044$ \\
Internal Rate of Return (IRR) (\%) & $13 \%$ \\
Achieved Return on Equity (\%) & $16 \%$ \\
\hline
\end{tabular}

Table 6. Results for government buildings.

\begin{tabular}{cc}
\hline Parameter & Value \\
\hline Electricity Tariff (\$c/kWh) & 8.58 \\
Weighted Average Cost of Capital (WACC) $(\%)$ & $10.10 \%$ \\
Net Present Value (NPV) (\$) & $(\$ 500)$ \\
Internal Rate of Return (IRR) (\%) & $10 \%$ \\
Achieved Return on Equity (\%) & $11 \%$ \\
\hline
\end{tabular}

Table 7. Results for industrial buildings

\begin{tabular}{cc}
\hline Parameter & Value \\
\hline Electricity Tariff $(\$ \mathrm{c} / \mathrm{kWh})$ & 6 \\
Weighted Average Cost of Capital $($ WACC) $(\%)$ & $10.10 \%$ \\
Net Present Value $(N P V)(\$)$ & $(\$ 8867)$ \\
Internal Rate of Return $(I R R)(\%)$ & $5 \%$ \\
Achieved Return on Equity $(\%)$ & $4 \%$ \\
\hline
\end{tabular}

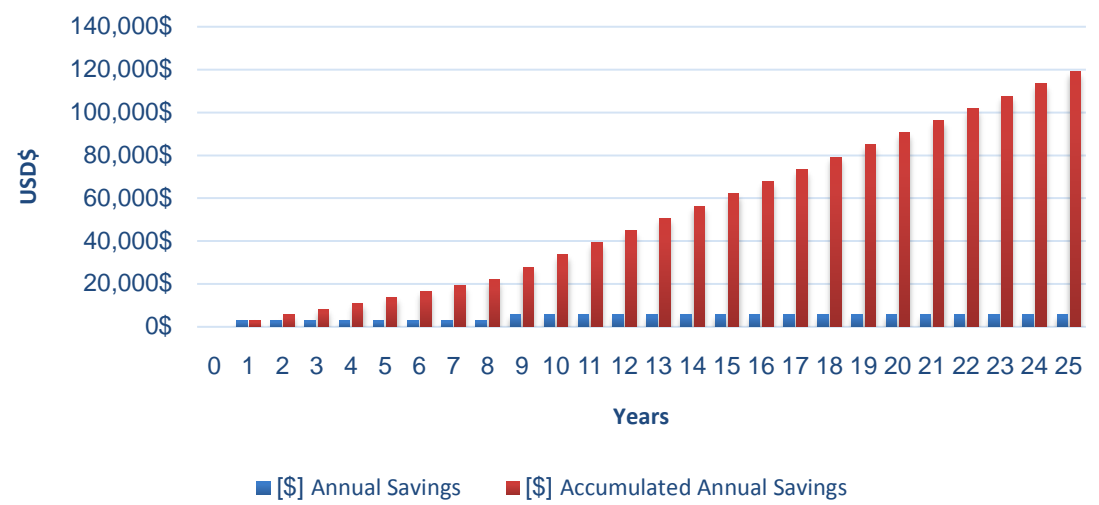

Figure 4. Annual saving and cumulated annual savings (Residential sector). 


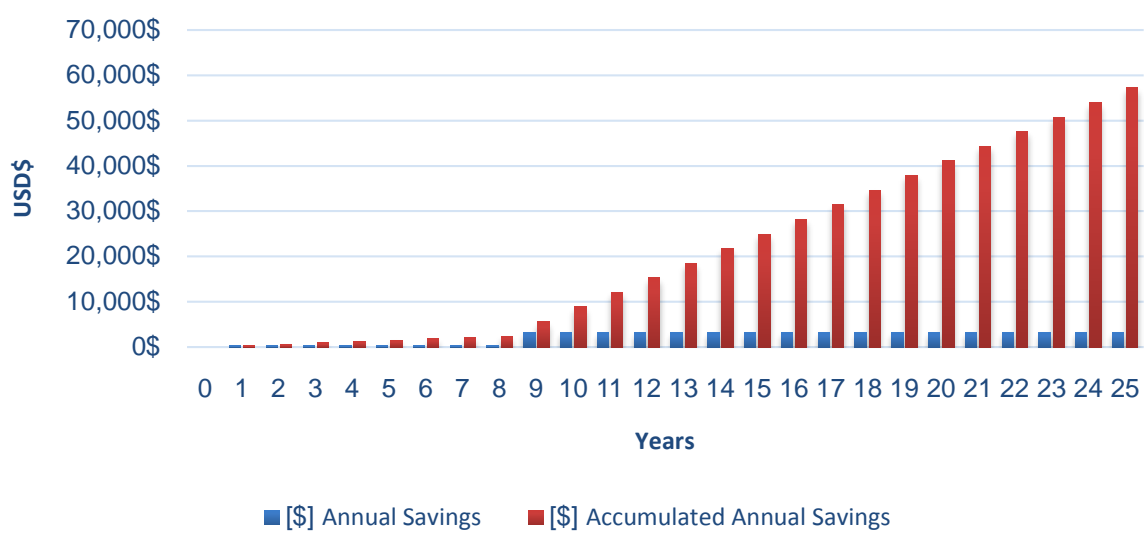

Figure 5. Annual saving and cumulated annual savings (Commercial sector).

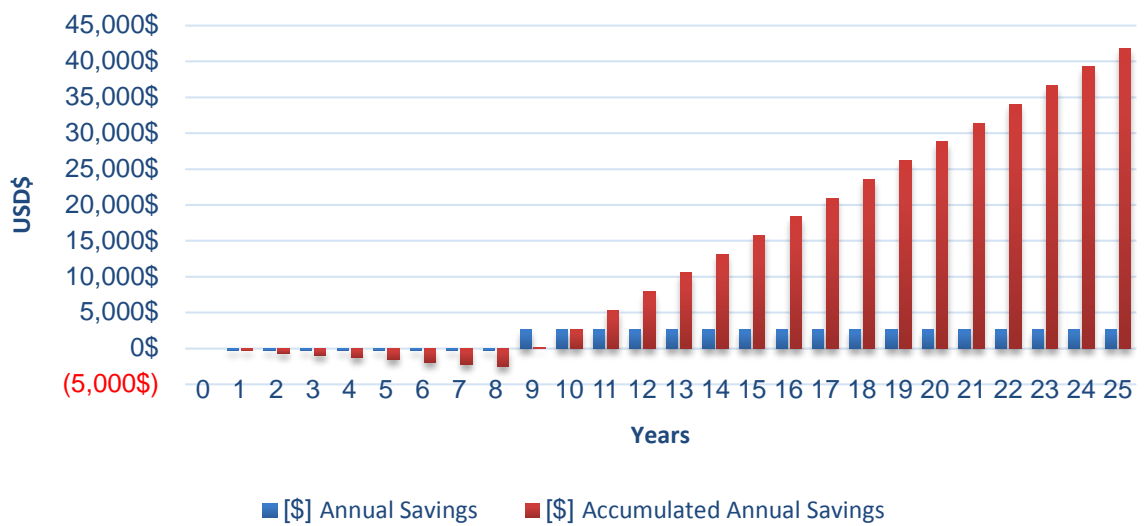

Figure 6. Annual saving and cumulated annual savings (Government sector).

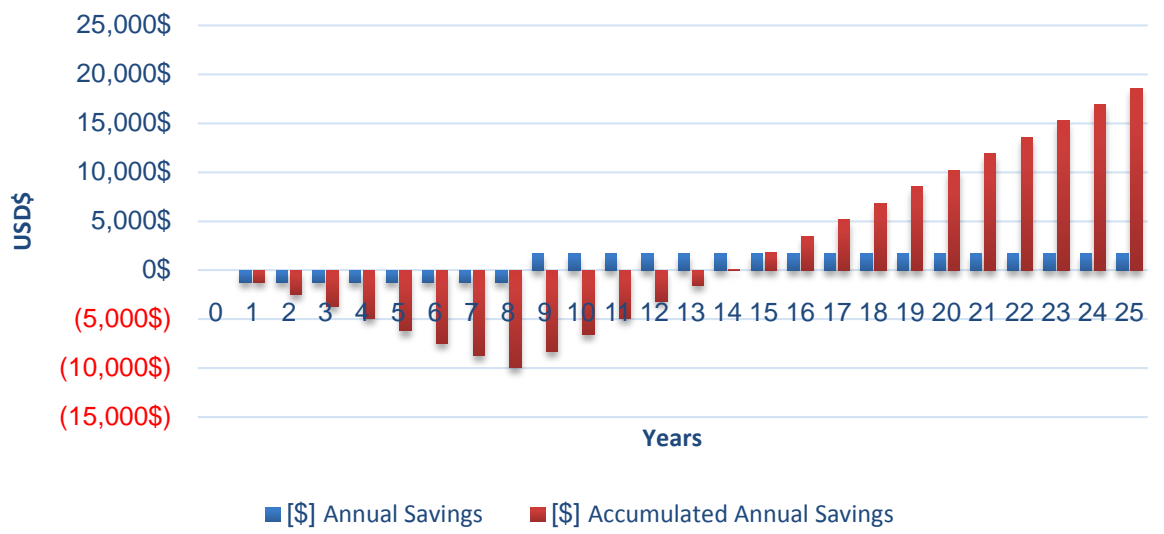

Figure 7. Annual saving and cumulated annual savings (Industrial sector)

to resort to a net-metering mechanism that would rely mainly on electricity balance settlements rather than financial transactions.

\section{Acknowledgements}

The authors would like to thanks the Information Center and Renewable Energy department, Ministry of Electricity, Iraq for helpful to get the required data and for encouragement and support to complete this work. 


\section{Conflicts of Interest}

The authors declare no conflicts of interest regarding the publication of this paper.

\section{References}

[1] Wolfram, C., Shelef, O. and Gertler, P. (2012) How Will Energy Demand Develop in the Developing World? Journal of Economic Perspectives, 26, 119-138. https://doi.org/10.1257/jep.26.1.119

[2] Rodrigues, S., Torabikalaki, R., Faria, F., Cafôfo, N., Chen, X.J., Ivaki, A.R., Mata-Lima, H. and Morgado-Dias, F. (2016) Economic Feasibility Analysis of Small Scale PV Systems in Different Countries. Solar Energy, 131, 81-95.

https://doi.org/10.1016/j.solener.2016.02.019

[3] Sajjad, I.A., Manganelli, M., Martirano, L., Napoli, R., Chicco, G. and Parise, G. (2018) Net-Metering Benefits for Residential Customers: The Economic Advantages of a Proposed User-Centric Model in Italy. IEEE Industry Applications Magazine, 24, 39-49. https://doi.org/10.1109/MIAS.2017.2740459

[4] Lawson, A.J. (2019) Net Metering: In Brief. Congressional Research Service.

[5] Tan, R.H.G. and Chow, T.L. (2016) A Comparative Study of Feed in Tariff and Net Metering for UCSI University North Wing Campus with $100 \mathrm{~kW}$ Solar Photovoltaic System. Energy Procedia, 100, 86-91. https://doi.org/10.1016/j.egypro.2016.10.136

[6] El Tous, Y. and Abdelhafith, S. (2013) Feasibility of Residential Grid Connected PV System under the Jordanian Net Metering Renewable Energy Law. Journal of Energy Technologies and Policy, 3, No. 7.

[7] El-Tous, Y. (2012) A Study of a Grid-Connected PV Household System in Amman and the Effect of the Incentive Tariff on the Economic Feasibility. International Journal of Applied Science and Technology, 2, No. 2.

[8] Gupta, C. and Singh, S. (2016) Feasibility Analysis of 1 MW Grid Connected Solar Rooftop Plant. International Journal of Computer Science and Electronics Engineering (IJCSEE), 4, No. 3.

[9] Syafii, Novizon, Wati and Juliandri, D. (2018) Economic Feasibility Study of Rooftop Grid Connected PV System for Peak Load Reduction. 5th International Conference on Electrical Engineering, Computer Science and Informatics (EECSI), Malang, 16-18 October 2018. https://doi.org/10.1109/EECSI.2018.8752957

[10] Holdermann, C., Kissel, J. and Beigel, J. (2014) Distributed Photovoltaic Generation in Brazil: An Economic Viability Analysis of Small-Scale Photovoltaic Systems in the Residential and Commercial Sectors. Energy Policy, 67, 612-617. https://doi.org/10.1016/j.enpol.2013.11.064

[11] AlAhamad, I.M. (2018) A Feasibility Study of Roof-Mounted Grid-Connected PV Solar System under Abu Dhabi Net Metering Scheme Using HOMER. Advances in Science and Engineering Technology International Conferences (ASET), Abu Dhabi, 6 February-5 April 2018. https://doi.org/10.1109/ICASET.2018.8376793

[12] Yoomak, S., Patcharoen, T. and Ngaopitakkul, A. (2019) Performance and Economic Evaluation of Solar Rooftop Systems in Different Regions of Thailand. Sustainability, 11, 6647. https://doi.org/10.3390/su11236647

[13] Imam, A.A., Al-Turki, Y.A. and Kumar R., S. (2020) Techno-Economic Feasibility Assessment of Grid-Connected PV Systems for Residential Buildings in Saudi Arabia-A Case Study. Sustainability, 12, 262. https://doi.org/10.3390/su12010262

[14] Annual Statistical Report 2018. IT Center, Ministry of Electricity, Iraq. 
[15] Ong, T.S. and Thum, C.H. (2013) Net Present Value and Payback Period for Building Integrated Photovoltaic Projects in Malaysia. International Journal of Academic Research in Business and Social Sciences, 3, No. 2.

[16] Almaktara, M., Abdul Rahmanb, H. and Hassan, M.Y. (2016) Economic Analysis Using Net Present Value and Payback Period: Case Study of the 9kWp Grid-Connected PV System at UTM, Johor Bahru Campus. Applied Mechanics and Materials, 818, 119-123. https://doi.org/10.4028/www.scientific.net/AMM.818.119

[17] Chaianong, A., Bangviwat, A., Menke, C., Breitschopf, B. and Eichhammer, W. (2020) Customer Economics of Residential PV-Battery Systems in Thailand. Renewable Energy, 146, 297-308. https://doi.org/10.1016/j.renene.2019.06.159

[18] Ondraczek, J., Komendantova, N. and Patt, A. (2015) WACC the Dog: The Effect of Financing Costs on the Levelized Cost of Solar PV Power. Renewable Energy, 75, 888-898. https://doi.org/10.1016/j.renene.2014.10.053

[19] AUE 2016, Arab Union of Electricity, Annual Bulletin 2016. http://www.auptde.org/ 